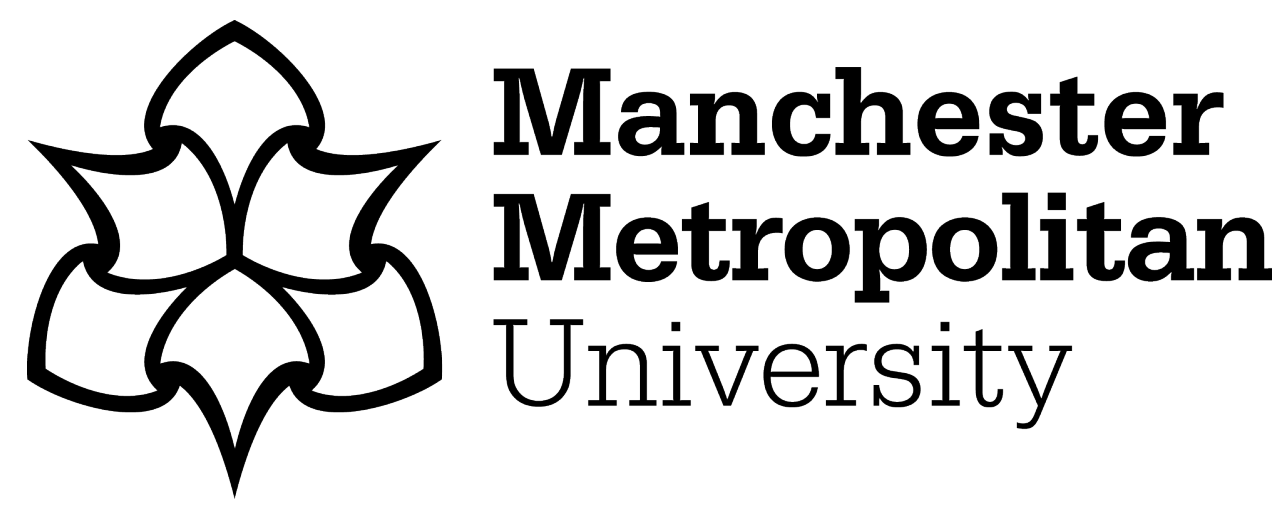

Hampton, MP and Jeyacheya, J (2015) Power, Ownership and Tourism in Small Islands: Evidence from Indonesia. World Development, 70. pp. 481495. ISSN 0305-750X

Downloaded from: https://e-space.mmu.ac.uk/620966/

Version: Accepted Version

Publisher: Elsevier

DOI: https://doi.org/10.1016/j.worlddev.2014.12.007

Please cite the published version 


\title{
Power, Ownership and Tourism in Small Islands: evidence from Indonesia.
}

Mark P. Hampton ${ }^{1}$ (University of Kent) and Julia Jeyacheya (University of Kent)

\section{Contact author:}

Kent Business School, University of Kent, Canterbury CT2 7PE, UK

Email: m.hampton@kent.ac.uk; Tel: 44 (0)1227 827726 general office

\begin{abstract}
This paper examines the political economy of tourism development in islands and uses Gili Trawangan, Indonesia as a case study. A longitudinal study drawing from fieldwork contributes to the discussion of how different types of power shape community development, and how the effects of hosting international tourism play an explicit role. Analysis using Barnett and Duvall's Taxonomy of Power model reveals the interplay between the types of power over time and its effects on different actors. Results raise questions for Less Developed Countries, and particularly islands, concerning the social costs of using tourism for development.
\end{abstract}

Key words: tourism; island economies; communities; political economy; Asia; Indonesia

\section{INTRODUCTION}

Governments in many Less Developed Countries (LDCs) have, since the late 1960s, focused their economic development strategies on international tourism. This is seen by many government planners as a key part of diversification strategies away from their reliance upon primary product exports, and tourism is seen as being a significant contributor to GDP, direct employment and government revenues (Scheyvens, 2011). 
This is particularly so for small island developing states (SIDS) where tourism has become a major sector in the Indian Ocean, Caribbean and across the Asia-Pacific region with some economies seeing tourism contribute more than $50 \%$ of GDP and a key source of direct employment (Hampton and Jeyacheya, 2013; Royle, 2001).

Indonesia, as in many other $\mathrm{LDCs}^{1}$, has also hosted growing international tourism since the late 1960s, initially with World Bank and other international assistance (Booth, 1990; Picard, 1996). Across the archipelago international tourism is spatially concentrated in certain islands and at the coast, with Bali remaining the dominant destination having the largest concentration of international tourists and tourism infrastructure (Badan Pusan Statistik, 2014). This paper however, uses a case study of small island tourism from Lombok, eastern Indonesia, to examine how community development issues are impacted by rapid tourism development and ownership patterns. The case study is more than just an interesting example of unplanned bottom-up tourism development in a developing small island. It stems from the fundamental question of why LDC governments have chosen tourism as a principal economic development tool. This is particularly relevant in destinations where community development is not well established and where the impact of an emerging tourism industry on local political processes can have a significant effect on how that community develops and how it operates. The case study raises fundamental questions about the influence of the political economy of tourism on socio-cultural development of a community where a sense of ownership and identity has become divided over time. This paper offers a nuanced reading and analysis of a LDC destination and uses a broad political economy approach as a lens to view power relations, building on the work of Baldacchino (1993), Bianchi (2002) and Ferguson (2011).

Barnett and Duvall's (2005) taxonomy of power model is applied here to "understand how ... outcomes ${ }^{2}$ are produced and how actors are differentially enabled and constrained to determine their fates" (Barnett and Duvall, 2005: 8). The model goes beyond the traditional concept of power where the social relations between actors $\mathrm{A}$ and $\mathrm{B}$ determines the capacity one can exert control over the other, and crucially, that the other has conceded in their subordinate role. This helps understand why the subordinate's capacity "to determine their circumstances and fate" (Barnett and Duvall, 2005: 42) is significantly reduced, but does help our understanding of the manner in which control is asserted and the effect this has on the 
social constitution of different actors. The taxonomy of power model considers that four forms of power "are simultaneously present" (ibid: 44) and are categorised as either direct or diffuse. The traditional concept of power is direct (compulsory power) and is exerted indirectly by a diffuse or distant relation (institutional power) with actors who are mutually constituted by their socially structured position (structural power). In this, capacity and advantage is differentially apportioned to different positions, thus constraining some "from recognising their own domination" (ibid: 54) and accepting their position. Productive power is the final form and is a "system of meaning and signification" (ibid:43) that is produced through diffuse social processes (as opposed to social relations) and discourse between actors, thereby producing a shared social identity and understanding of 'the world around them' and their capacity to take action. The taxonomy of power model provides a helpful framework for this paper within which to analyse the Gili Trawangan case study. This is done by first, exploring how the transition in power and governance evolved over a period of time from a range of different actors, and second, analysing how material and immaterial resources shaped local actors' capacity to affect (or not) a power change.

The paper is structured in five main parts. It begins by reviewing the main literature of tourism in small islands and small island developing states (SIDS) to explore why governments continue to see tourism as a key economic development tool and the main problems. The next section sets the broad context for the project by presenting an overview of national tourism development in Indonesia before outlining the methodology deployed by the authors. The main section of the paper then presents the Gili Trawangan case study and examines the political economy of tourism and in particular, the effects of decentralization and land reform on local communities. The following section then analyses significant changes in direct and diffuse power (compulsory, structural, institutional and productive power) by examining the social relations of the island's different actors over time. The final section ends the paper and offers some conclusions and suggestions for government policymakers and the continuing academic discussion of the thorny issues of power, ownership and local communities under tourism.

\section{TOURISM AND ISLANDS: A LITERATURE REVIEW}

Given the number of independent small states, and specifically Small Island Developing $\operatorname{States}^{3}$ (SIDS), island economic development studies have broadened and 
deepened significantly since the 1970s. Initially, the dominant orthodoxies, such as neoclassical growth models that had been used for large developing countries, were also applied to island development. However other approaches to island development can be tracked. In the mid 1980s the influential MIRAB model emerged (Bertram and Watters, 1985) based initially on analysis of South Pacific islands. MIRAB (MIgration, Remittances, Aid and Bureaucracy) and the later, TOURAB variant (TOURism, Aid, Bureaucracy by Guthunz and Von Krosigk, 1996) attempted to show the island economies' response to exogenous change. Other aspects were also being discussed at this time such as Briguglio (1995) who focused on islands' economic vulnerabilities with the highly cited vulnerability index, and more recently there has also been some academic interest in considering the 'resilience' of islands as perhaps a counter model (Hamzah and Hampton, 2013; Scheyvens and Momsen, 2008). Similarly Baldacchino (1993) suggested that small islands could in fact be fast and flexible within the international political economy and he highlighted the role of key individuals in islands as 'change agents' compared with larger polities that are arguably slower to react to changing economic circumstances. The political economy approach and the political ecology variant (Cole, 2012; Gossling, 2003; Stonich, 1998) have been increasingly applied in tourism development to explore the relationships between different stakeholders and understand how political forces interact and generate change at a destination level.

More recently, the concept of 'inclusive growth' has started to be explored in the context of small island economies, with institutions such as the World Bank and Commonwealth Secretariat among others organizing workshops and commissioning studies. ${ }^{4}$ The continuing importance of tourism to many small island economies has been reflected in the acronym SITE (Small Island Tourist Economies) by writers including McElroy (2006); Oberst and McElroy (2007) and Shareef, (2004). In terms of tourism and the wider international development literature, there has been discussion around the issues of economic impacts affecting host communities, specifically some controversy over 'trickle down' mechanisms versus pro-poor ${ }^{5}$ tourism: see for instance Harrison (2008) versus Goodwin (2008).

However, there has been a surprising lack of debate on tourism in LDCs in the mainstream academic international development discourse. For instance, in this journal itself, there has only been a handful of recent papers published on tourism and development in World Development since the early 2000s. Third World Quarterly 
published a special issue on tourism and development and especially the debates over pro-poor tourism, but this was in 2008. For instance, The Journal of International Development does not appear to have published any article specifically on tourism, but an article published in 2008 focused on tourism and revenue leakage from local rural communities in Uganda. More recent articles in World Development (2011 and 2013) refer to tourism development as one of a few alternative economic development tools for small states or small island states particularly, which are undergoing structural and trade reforms. ${ }^{6}$

That said, as expected, specialist academic tourism journals such as Annals of Tourism Research; Tourism Management and the Journal of Sustainable Tourism cover the topic regularly. Whilst some new research has appeared that critically examines the role of tourism in poverty alleviation (for instance see Mitchell and Ashley, 2010; Scheyvens, 2011, Winters et al., 2013), and there is a limited set of writers adopting a focus on the political economy of tourism (for example: Bianchi, 2002; Britton, 1982; Ferguson, 2010, 2011; Lee et al., 2014), there does not seem to have been significant debate within mainstream international development journals.

Nevertheless, for development agencies and practitioners there is considerable interest in tourism for development (Scheyvens, 2002) with recent initiatives by the World Bank, Commonwealth Secretariat, UN World Tourism Organization and ILO among others examining the role of tourism in the economic growth of SIDS ${ }^{7}$ (Hampton and Jeyacheya, 2013; UN WTO, 2012a, UN WTO/ILO, 2013).

\section{PROJECT CONTEXT}

(a) Tourism development in Indonesia

International tourism to Indonesia effectively began in the colonial period with some small-scale tourism in destinations such as Bali starting in the 1920s with the official encouragement of the Dutch colonial government (Picard, 1996). However, largescale international tourism became part of central government development planning under Suharto's New Order regime, appearing in the central Five Year Plans (Repelita) from 1969. Since then tourism has undergone significant changes. From small absolute numbers of visitors in the 1960s and 1970s, the sector experienced rapid growth in the 1980s and 1990s, accelerating from around one million international arrivals in 1987, doubling to over 2.17 million by 1990, and reaching a peak in the mid 1990s with around 5.2 million international arrivals in 1996 (data 
from Badan Pusan Statistik). ${ }^{8}$ After that high point in terms of international tourist numbers, the country then experienced a sequence of major problems that affected tourism: the Asian economic crisis of 1997-8 and the associated fall of the Suharto New Order regime; repeated regional problems from the massive haze from forest clearances fires; the 2002 Bali terrorist bombings (Hitchcock and Darma Putra, 2005) and the 2004 Boxing Day tsunami. (See Figure 1). Despite this unprecedented sequence of crises, international arrivals have been growing since 2006 and in 2013 a new peak was recorded of 8.8 million international visitors (Badan Pusan Statistik, 2014).

Figure 1. International Tourism Arrivals (000), Indonesia: 1995-2012

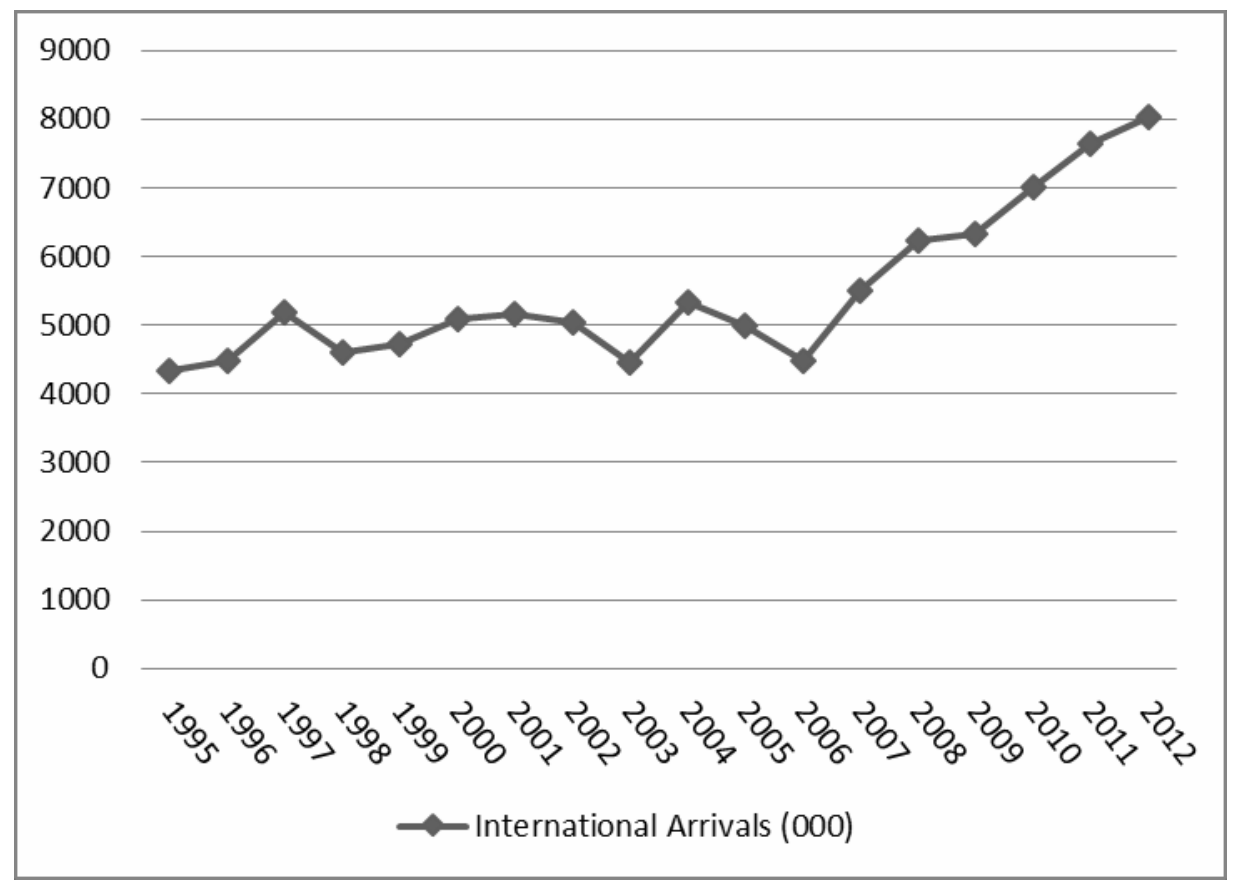

Source. UNWTO Highlights 1996-2012

This growth in tourism needs to be seen within the broader context of the time when international tourism was increasingly being advocated as an engine for growth for LDCs with encouragement from international players such as the OECD and World Bank (OECD, 1967; de Kadt, 1979). By the early 1970s ambitious large-scale, capital-intensive planned tourism resort developments such as Nusa Dua in southern Bali were being funded with assistance from the World Bank and UNDP. This was 
partly because, at that time international tourism development was viewed by international agencies and governments as a panacea for the economic and social challenges facing LDCs in general, and later, specifically in the SIDS. By the 1980s, as in many other LDCs, tourism in Indonesia was part of a diversification strategy away from a reliance on primary product exports and agriculture and this arguably benefitted from broader deregulation of non-oil sectors through fewer bureaucratic procedures and relaxed visa restrictions for example (Booth,1990).

Tourism was primarily planned for Bali, the leading destination, but Yogyakarta in Java was also seen by government planners as the second core destination to be developed (Dahles, 2002). The strategic focus on these two destinations for tourism development was driven by their increasing popularity with international tourists and the clear economic potential of tourism over traditional exports. The growth in unplanned tourism began in the early 1970s with the hippy travellers on the overland trail of the ' $3 \mathrm{Ks}$ ' of Asia (Kabul, Kathmandu, Kuta, Bali). By the 1980s the growing numbers of backpackers promoted new destinations at Lake Toba (Sumatra), Jakarta, Yogyakarta and Bali, and later the Gili islands of Lombok and further eastwards via Komodo and Flores (McCarthy, 1994, Hampton, 2013). Subsequently in the 1990s large scale investment projects were being encouraged in Bali and Yogyakarta, as well as Bintan island near Singapore leading to the construction of the massive Bintan Beach International Resort (Shaw and Shaw, 1999; Hampton, 2010; Bunnell et al., 2012).

The pattern of development in Indonesia shows a broad division between the centrally planned large, and generally successful, integrated resorts in Bali and Bintan alongside an extremely uneven spatial distribution of tourism between different parts of the archipelago. Apart from Java, Bali and to some extent Bintan, for most of the other larger islands such as Sumatra, Kalimantan and Sulawesi, let alone other smaller islands such as Flores and Sumbawa, international tourism remains very small, with low visitor numbers. Recently the central government's National Tourism Development Master Plan 2010-2025 was an attempt to diversify tourism. With a renewed emphasis away from Bali and the existing core areas this ambitious program aims to encourage tourism in around 50 areas and setting up new DMOs (Destination Management Organizations). In late 2012 the central government launched a new Strategic Plan for Sustainable Tourism and Green Jobs for Indonesia jointly with the ILO (Ministry of Tourism and Creative Economy/ILO, 2012), which aims to refocus 
the tourism sector towards having a more sustainable basis. As seen in the 1970s, Indonesia's renewed tourism development strategies have been shaped by revised international agendas that now call for a holistic and integrated approach to development, where tourism is considered in a more critical light and a central pillar in national development strategy. The UN Millennium Development Goals (MDGs) (2000-2015) for example, have led to LDC governments using tourism to assist in achieving some of those goals such as poverty alleviation and environmental sustainability (Sasidharan and Hall, 2012). More recently alternative economic growth models proposed by international organizations identify tourism playing an important role in inclusive growth strategies (World Bank, 2012a), the green economy (UNEP/UN WTO, 2012) and the 'blue economy' (World Bank, 2012b). These are all potential avenues for LDCs to explore in the wake of the MDGs.

\section{(b) Methodology}

Within the body of field research-based tourism studies, as Xiao and Smith (2006) noted there is a lack of longitudinal studies and most are based upon single visits (Cole, 2004).${ }^{9}$ However, this paper reports on part of a longitudinal study in an LDC tourism destination. One author worked on these islands in the mid 1990s, and has made several visits since. Earlier work included beach surveys, site mapping and a series of interviews. In the more recent fieldwork in 2011 on which this present paper reports, constraints of a small budget and limited time in the field meant that a rapid rural appraisal (RRA) type approach was the most appropriate (Theis and Grady, 1991). Although the authors recognize the criticisms of the RRA approach, it was chosen as an appropriate tool to maximize data collection over a relatively short, but intense, fieldwork period, and to listen to local voices (Chambers, 1983). The field work was carried out in September 2011 over a three week period by one author and with support from a post-doctoral research assistant, and a range of tools were used including, semi-structured interviews $(n=24)$, participant observation, beach surveys and site mapping.

The respondents who participated in the field research in 2011 were selected using 'snowball' sampling ( $\mathrm{n}=20)$ to find key 'gatekeepers' and gain access to other key players in this small island community (Gurza Lavalle et al., 2005) who were employed in tourism sectors and in different capacities. Others were approached 
using convenience sampling $(n=4)$ as the researchers were going about their business on-island.

A broad analysis of 20 'snowballed' respondents shows 6 local males were owners (5) or managers (1) of dive shops, restaurants or accommodation, while 2 coowned a cultural organization and 2 waited on tables and staffed the reception desk in separate villas. Local government members (former and previous) were also interviewed on recommendation by a few respondents (2). Only 3 males were foreigners and they were either involved in the accommodation or dive sectors. A smaller proportion of respondents were female (8) and foreign (90\%); however they represented a range of economic and non-economic activity on the island including managing or co-owning accommodation, dive shops or restaurants, as well as an environmental NGO.

The convenience sample was used to increase the number of female respondents and expand the range of operators. Due to time constraints on the researchers as well as business owners / managers, only 4 additional respondents were included. They were however all local people whose businesses were directly or indirectly benefitting from tourism including a wholesaler (female owner), a fast boat operator, a restaurant manager and a dive shop owner.

Although the visiting author sought out previous respondents, it was established quite early on that few local people from the 1990s remained on the island, were available at the time of the visit or indeed had deceased. Having said that, the sample of respondents (24) was representative of the island's population with $58 \%$ (14) local people (from Gili Trawangan, Gili Air and Lombok), and within that group more than half (8) had lived on the island for over 10 years and 3 had been residents since the 1970s when the island was first inhabited (30-40 years). The remaining respondents (10) were foreigners who had resided on the island from 3 months to 16 years and were from the UK (4), Australia (2), Canada (1), Austria (1), France (1) and New Zealand (1).

The average interview duration was 45 minutes, however those completed with long-term residents lasted an average 90 minutes because they were able to recount the island's historic development as tourist numbers increased. A few interviews (3) were shorter than the average duration (approximately 25 minutes) because the respondents had only recently arrived on the island (less than 1 year). All interviews were digitally recorded and the respondents were guaranteed strict 
anonymity. This was crucial given the size of the island. The interviews were conducted at business premises and in communal areas such as the restaurant or a working space, at non-peak times.

The interviews were manually coded and assigned a random number between 1 and 24 before being transcribed on return to the home university. The transcripts were analyzed using qualitative data analysis software (NVivo). This process employed a range of tools to search for content and code responses according to specific criteria; in this case the primary categorization phase differentiated respondents according to age, gender, nationality, employment and length of stay on Gili Trawangan. The second phase focused on variables that were relevant to this study's line of enquiry and included 'nodes' (categories) such as tourism impacts, development, challenges, opportunities and business operations, and 'child nodes' (sub-categories). The results were collated by generating reports that linked and mapped responses according to selected variables (nodes and child nodes), and quotes were selected from the reports.

The quality of the interviews was satisfactory and, in spite of a translator being available, all respondents were able to converse in English to a reasonable level. This is not unusual for popular destinations that attract mainly Western tourists, and particularly so in small island communities.

\section{GILI TRAWANGAN, INDONESIA}

Gili Trawangan is located in the Nusa Tenggara Barat (West Nusa Tenggara) province and lies at the northwest tip of Lombok in eastern Indonesia (Figure 2). ${ }^{10} \mathrm{It}$ is the largest of a group of three islands (the others being Gili Meno and Gili Air) that have attracted small-scale tourism tourists since the mid 1980s. The island's relative remoteness and its slow, limited access from main tourism areas such as Bali, meant that its initial tourism development between the mid 1980s and late 1990s catered mainly for backpackers and a small number of scuba divers. Infrastructure consisted of small, basic accommodation units, typically bungalows, constructed from traditional building materials such as bamboo and wood that were sourced locally (Hampton, 1998; Kamsma and Bras, 2000). The first accommodation businesses were established in 1985 by local islanders, and by 1989 three dive shops had also opened to accommodate small numbers of mainly Australian divers (Bottema and Bush, 2012). 
Figure 2. A map showing Gili Trawangan and its neighboring islands.

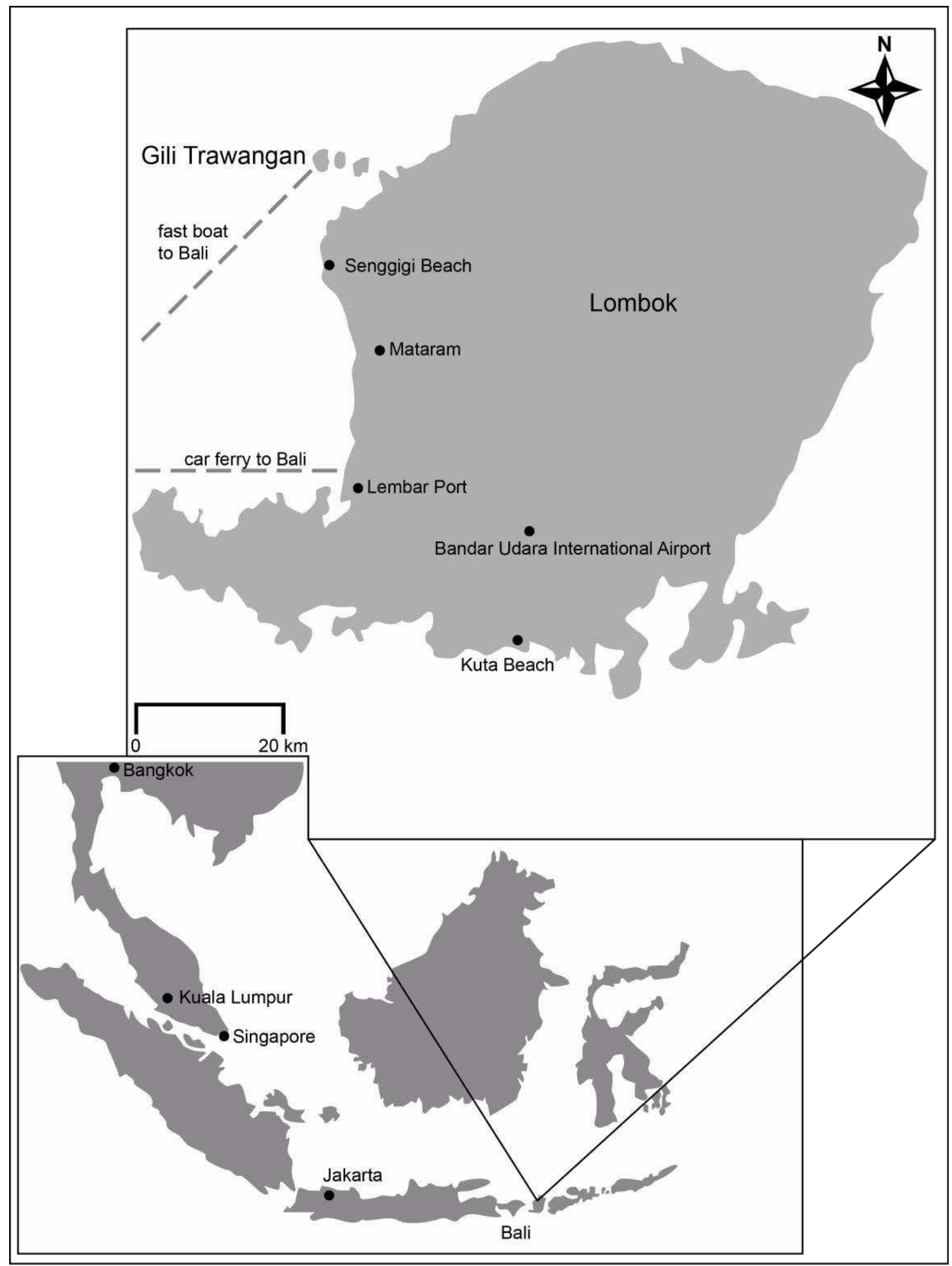

Source. Primary researcher's field notes 
Throughout the 1990s Gili Trawangan gained popularity with backpackers from Europe and Australasia being on the well-worked trail across Indonesia from west to east. In addition, the island was also starting to attract dive tourists. This booming tourism sector then attracted labor migration from neighboring islands and Lombok to fill the employment shortage in the growing accommodation, bar and restaurant sectors, and others arrived to invest in land or small enterprises (Cushnahan, 2004). Tourism businesses were also set up by backpackers who had decided to stay on the island - what Brenner and Fricke (2007) dub 'developer tourists' - and they specialized in dive shops and accommodation with or without catering services (Kamsma and Bras, 2000). During this early development phase only $10 \%$ of the workforce was from outside the immediate area ${ }^{11}$ however they tended to live on the island, only returning home for annual leave or occasional weekends. Access to the island was limited to small outrigger boats between Gili Trawangan and Lombok, and few modern facilities such as ATMs, air conditioning or wi-fi (Hampton and Hampton, 2009).

This growth in tourism demand led to inward migration from neighboring islands (Gili Meno, Gili Air and Lombok) increasing the population on Gili Trawangan from 400 people in 1996 (Hampton, 1998) to 1089 inhabitants in 2003 (Satria, Matsuda and Sano, 2006). As the resident population increased, ${ }^{12}$ land values increased and rapid, unplanned and contentious tourism development projects shifted the attraction of the islands to higher value visitors and wealthy outside investors. The contention at this time was related to local laws on planning and natural resource protection that were being flouted by outside investors. Although strategies were used by local actors to cope with early disputes, such as breaking down fences and returning to the land, later on this strategy was not effective because policy reform and decentralization brought in new actors, which upset the status quo. ${ }^{13}$ With accommodation and restaurant businesses catering to western standards and promoting themselves to a young, affluent tourist market seeking sun, sea and sand and diving holidays (Dodds, Graci and Holmes, 2010), the backpacker market (and its subsequent local supply chain) appeared to be gradually priced out. Rising land and real estate prices resulted in local budget accommodation relocating to cheaper areas further behind the immediate beach strip (Vaisutis et al. 2007). Sketches of coastal tourism development in the south of the island during the mid 1990s are shown in Figures 2 and 3. Note that during this time the number of restaurants, shops and 
accommodation units were in single digits, with ownership of businesses mostly in local hands. Much of the island was used for agriculture or other purposes at this time with tourism development occupying a small total area.

Figure 3. Tourism Development on Gili Trawangan's south coast, 1996

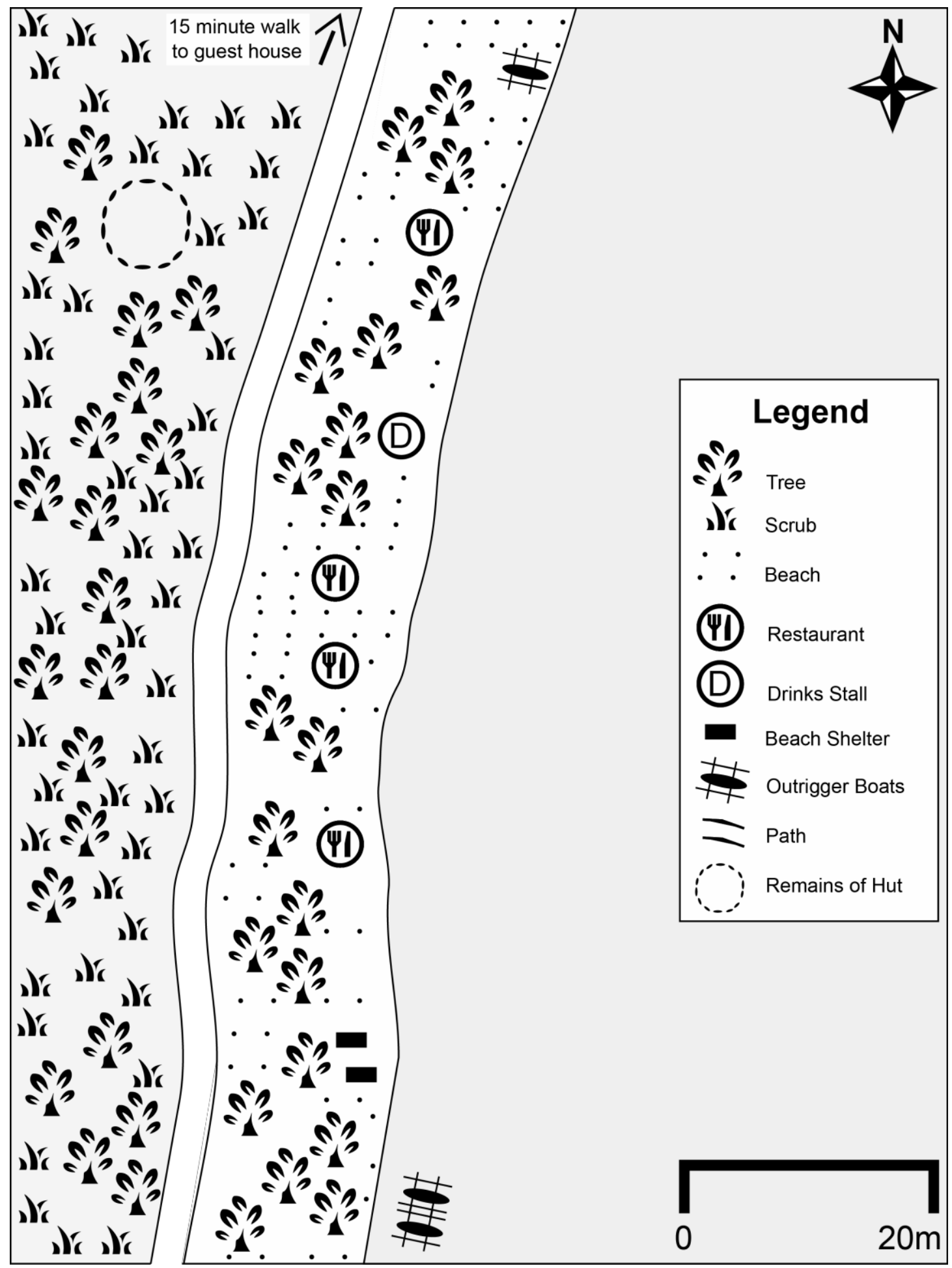

Source. Primary researcher's field notes 
Figure 4. Tourism Development on Gili Trawangan's south coast, 1997

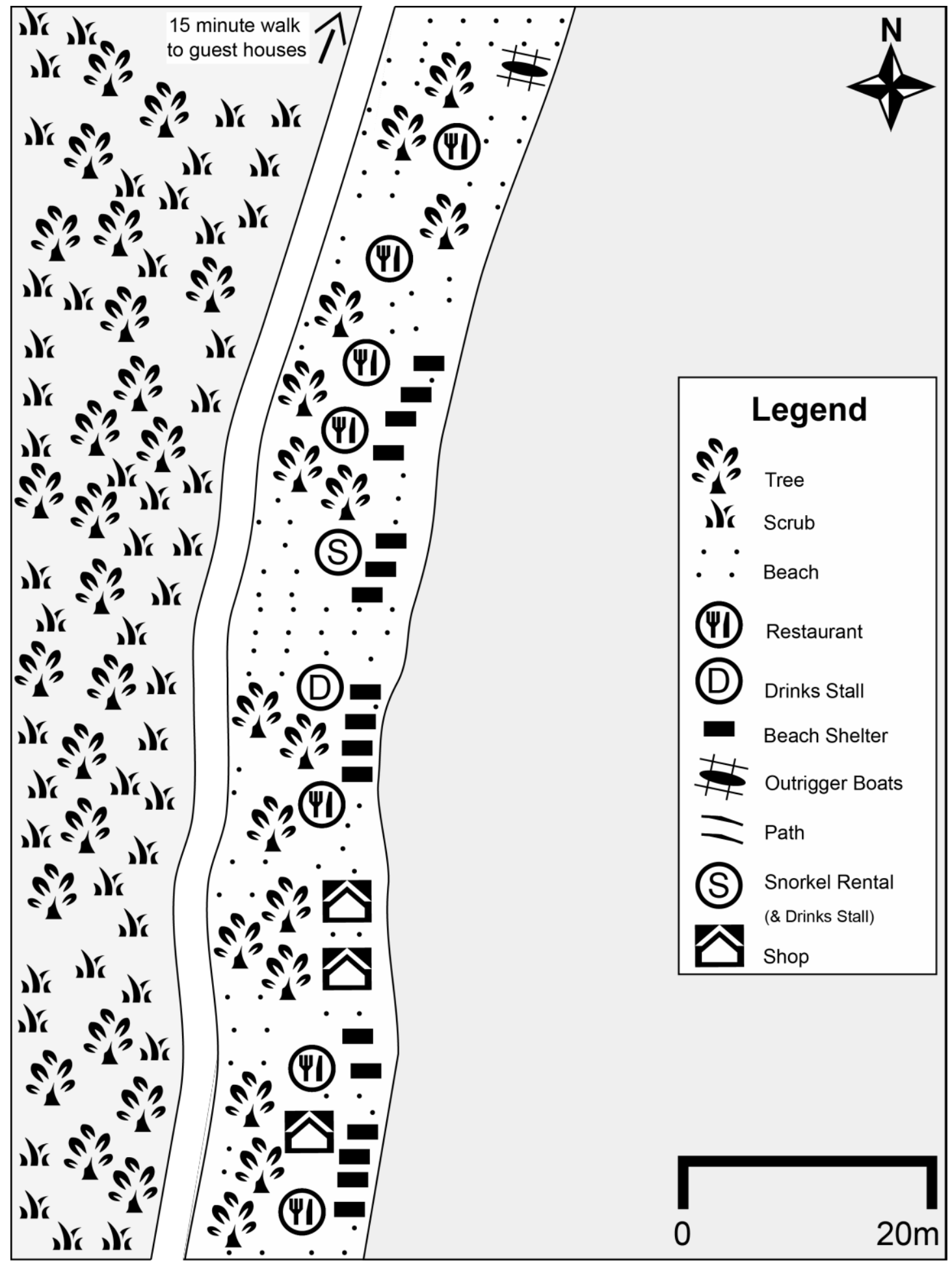

Source. Primary researcher's field notes

Fieldwork observations in 2011 showed that small-scale agricultural and seaweed production had almost ceased and coconut and copra production had decreased significantly. Land previously used for growing food crops such as corn and peppers, 
had been developed for tourism and where land ownership issues continue, opportunities for those local people remained potentially short-lived or even nonexistent. The only transport continues to be cidomo (horse-drawn buggies) or bicycle as motorized vehicles are not permitted on the island; this is in accordance with traditional rules (adat). The simple network of pathways has been expanded to accommodate the rise in tourist accommodation, scuba facilities (dive shops/schools), restaurants and bars to the north and west of the island, and there are plans to build a road around the island's perimeter. This is a contentious issue with local people because it delegitimizes the traditional rules governing the island's development. "They are talking about putting a road here. I think the people here would fight it to the death. But I don't know. I don't know who rules this place. I know there is a chief but I don't know how powerful they are" [emphasis added] (Respondent 4).

From around 2008, a new fast inter-island boat service provided direct access to Gili Trawangan from Bali as well as more frequent access from Lombok. Fast, direct access from Bali, the largest tourism destination in Indonesia, facilitated a step change in the tourism in Gili Trawangan. ${ }^{14}$ The number of fast boats grew to 16 by 2011 further accelerating tourism growth on the island. The short journey time and direct route between Gili Trawangan and other major destinations in the region meant tourists could afford to spend fewer days on the island than previously, using it as a short-break from the more chaotic, busy experiences elsewhere. ${ }^{15}$ By 2011 development had extended to the east and northern reaches of the island, with the central inland area remaining undeveloped but increasingly under pressure from speculators and developers. Furthermore the number of permanent and temporary structures encroaching on the beach was significant (see Figure 4$)^{16}$. 
Figure 5. Tourism Development on Gili Trawangan's south coast, 2011

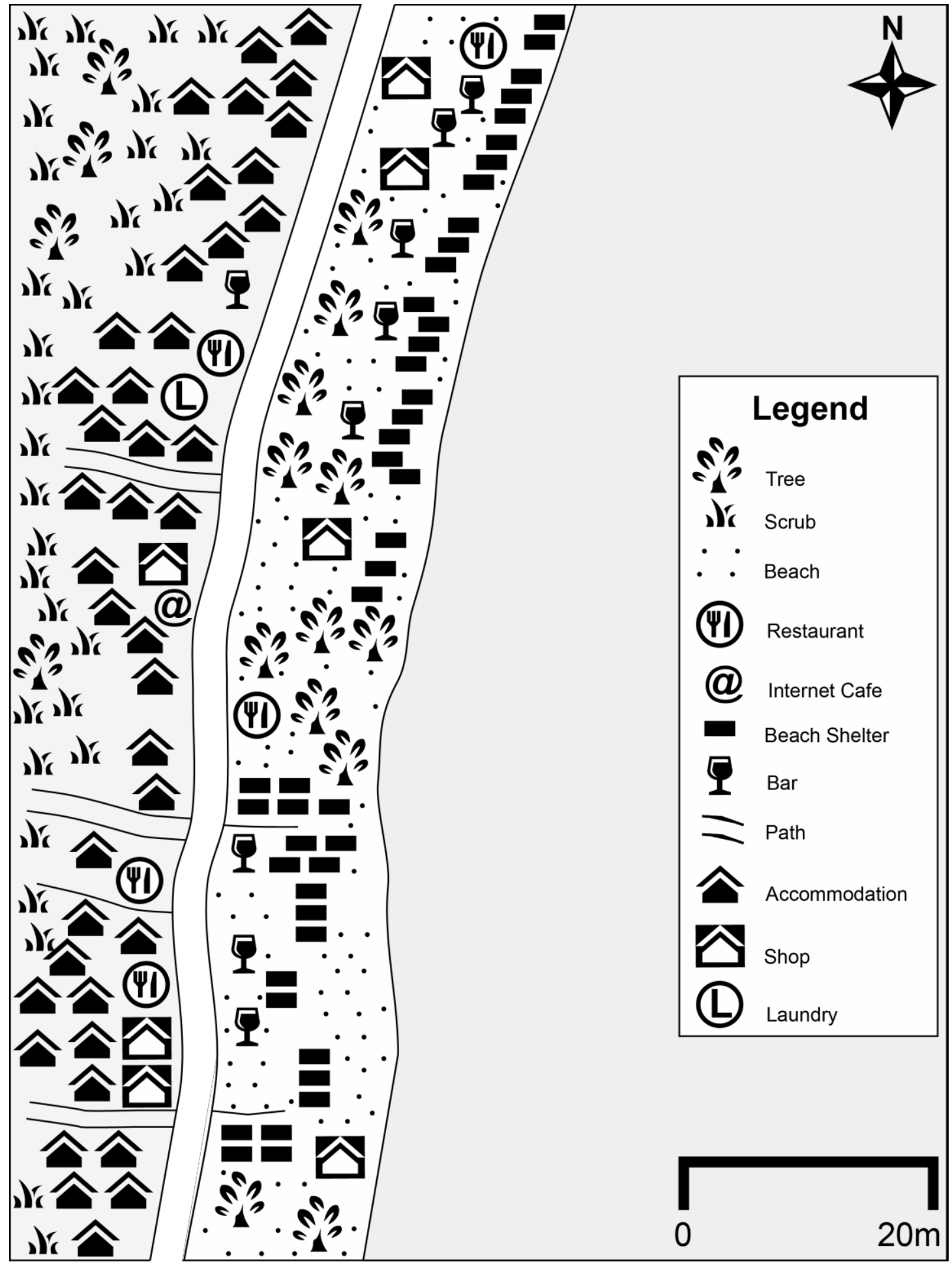

Source. Primary researcher's field notes

The transition in the tourist lifecycle from development to consolidation stage (Butler, 1980) has influenced the dynamics of island life and the integrity of the environment (marine and terrestrial), and it is arguably during this step change when a new power 
structure and system of governance took form on the island. It is clear, in this instance, that the interest and indeed the motivation of regional and national governments to promote tourism development on Gili Trawangan in the late 2000s was driven by economics. However, this first reading of the situation will be augmented by deeper analysis that will show how underlying changes relating to the value and use of land, ownership patterns, and governance of the land and sea, for example, have indirectly shifted the focus to tourism as a main economic development tool.

a) Power, Governance and Tourism on Gili Trawangan

The political system on Gili Trawangan followed traditional rules (adat) and regulations (awig-awig) with a headman (kepala desa) overseeing the island's progress. This included early tourism development, which was gradual and driven by local tourism entrepreneurs (Satria, Matsuda and Sano, 2006) who were the first inhabitants to settle on the island and were granted official land rights ${ }^{17}$ for coconut plantations and other agricultural activities (Dickerson, 2008). As the national and regional governments were focused on developing Bali for international tourism, and later Lombok (Fallon, 2001), the relatively recent permanent island community lay outside national economic development plans. The spatial and political remoteness of the island from the national government in Jakarta enabled a bottom-up approach to development and seems to have created a strong sense of independence for the islanders. $^{18}$

In the early stages of the island's development (mid 1970s to mid 1980s), traditional rules (adat) which were enforced by the island's headman, represented and defined the local community with its two main ethnic groups of Sasak and Bugis people. With livelihoods based on farming and fishing, these tourism pioneers were able to combine their knowledge of the coral reef ecosystem with their land assets to develop small-scale, locally-owned tourism services. These enterprises supplemented a traditional, subsistence lifestyle which appeared to broadly maintain the cultural, social and political integrity of the local community. ${ }^{19}$

In the early 1990s, the economic and development potential of the Gili islands as a dive and beach destination, was seen as a lucrative development options with national and regional political elites and wealthy outside investors. This led to the first of many, annual army-led land clearance operations in 1992 (McCarthy, 1998; 
Kamsma and Bra, 2000; Dickerson, 2008). This period of instability marked the beginning of a challenging shift in the political economy of the island and its tourism development. An account of this troubled time was recalled by Respondent 18, a resident since 1993 and originally from Sulawesi: "We knew the army was coming because every day, twice a day and twice a night we heard it on the radio. And then also they sent letters of warning to the villagers to get off the land. They were warning people through the radio. They told us they would clean up the area... People were very scared. It started . . from the trauma [army invasions and demolishing buildings] from before, the first in 1992, then 1993, then 1994."

The army continued to maintain a sizeable presence on the island throughout this period (albeit away from the main tourist area on the south coast), and prior to Suharto's exit from power in 1998, 15 year land certificates for small plots of land were issued to local families. Despite a small number of army personnel remaining on the island, the local community began developing the land for their own enterprise or leasing it to outside investors. Similarly, disputed land that had remained vacant since the 1980s was also reclaimed. This was not necessarily in defiance of the state but rather was in tradition with adat law ". . . if you sit on land for more than 10 or 12 years, you can claim it as your land" (Respondent 17).

Although the island continued to remain outside the government tourism planning process, it was clear from some respondents that this particular period marked a slow change in the rules of governance, particularly linked to land use rights for major tourist infrastructure (specifically large-scale accommodation and resorts).

Thus, ten years later in the late 2000s, the rapid rise in tourist numbers and outside investor-led tourism development had resulted in dramatic changes to the island's demography; to the social, economic and power relations among the different groups living and operating businesses in Gili Trawangan; and to the island's ecological integrity: "Before lots of tourists stayed here and invested businesses in this island, it was very calm and our lives were good and not too much hassle. But now with the investors coming to the island, they are money orientated... It's all about business, business, business." (Respondent 24)

Although the changes were peaceful during the first decade of decentralization, arguably this was because the island remained at the periphery of the state planning process. In 2011 the new land reform bill (UU 2/2012) was finally passed ${ }^{20}$ that proposed measures to boost 'crucial' infrastructure and more 
importantly, to ease the process of buying land for major public development projects including transport, public open spaces and housing (Deutsch, 2011). The bill was passed in December 2011 only three months after a renewed land clearance operation took place on Gili Trawangan called Operation Garain 2011. This is likely to transform the island community and its development goals significantly and represents the latest step change for Gili Trawangan.

b) Marine tourism development

The El Nino event in 1997-8 was the 'most extensive' coral bleaching event on record (Goreau, McClanahan, Hayes and Strong, 2000:5). It generated widespread coral reef mortality and significant economic losses to reef fishing communities. In order to maintain livelihoods, fishing communities around Lombok and the Gili islands employed destructive fishing practices - including explosives - which led to further reef damage and dwindling fish stocks. At the same time, the political transition into a post-Suharto era and changes to marine and land use policies took place (Curran, 2011:19); however the diffusion of benefits appeared slow and partial especially to those regions at the periphery.

Given the local community's role in initiating and leading tourism development since the 1980s, the lack of formal regulatory reform and security on Gili Trawangan had little impact. According to respondents, in the minds of the villagers the responsibility for protecting and policing the coral reefs remained theirs. The local villagers implemented traditional rule (awig-awig) over the coral reefs to protect them from further destruction and by doing so, they assumed responsibility for enforcing the rule through "monitoring, controlling and surveillance activities" (Wever, Glaser, Gorris and Ferrol-Schulte, 2012: 67). The policing of the islands' waters was, and continues to be, carried out by SATGAS (Gili Indah Youth Task Force). This community-led organization was established in 1998 in response to the decline in coral reefs and fish stocks, and it became a legitimate and influential group that filled a political vacuum during the transitional period. Subsequently, awig-awig was recognized by the then regional government, Lombok Barat Regency Government, as a necessary approach to managing the islands "given the regulatory changes to the governance of Indonesia's natural and marine resources" at the time (Curran, 2011:19), and this was formalized by SATGAS and the Regional Development Planning Board - BAPPEDA (Badan Perenncanaan Pembangunan 
Daerah). In 2003, the Gili Ecotrust NGO was established by developer tourists, and particularly dive tourists, with the explicit aim of protecting the coral reefs around the island and the restoring damaged reefs using Biorock technology. ${ }^{21}$ This NGO works closely with SATGAS and the regional government and also delivers regular coral management and Biorock workshops to communities, organizes beach clean-ups and land-based conservation projects across the three Gili islands (Gili Eco Trust, 2014). Although this strengthened the legitimacy of adat and local rule, as noted by Bottema and Bush (2012:45), the process of formalizing awig-awig was a divisive move for some local people. Satria et al.'s (2006: 112) observation of two types of conflict that resulted from this process -external allocation conflict (between fishers and marine tourism) and management mechanism conflict (between national and local government) - affected “ changes in social values and procedural fairness" among local people. The revivalism of awig-awig and adat as an outcome of the national decentralization process appeared to weaken its legitimacy in the eyes of the local people on Gili Trawangan, and in particular the fishers. Arguably, this was because the once community-led process of adat, and thus awig-awig, was now organizationled (national, local government and foreign organizations including NGOs and tourism businesses), was written in a formal language that was unfamiliar to many community members (Satria et al., 2006). Evidence from interview respondents suggested that this action disempowered and disenfranchised the local community. Subsequently, the "“constitutive political conditions' that ensnare the powerless, enclose the landless, and perpetuate clientelism in rural Indonesia" (Tyson, 2010: 4) was now beginning to influence and change the social relations among different community members on Gili Trawangan in early 2000. Members of the local fishing community interviewed during this research viewed the new awig awig document as privileging tourism entrepreneurs and marine tourism over their livelihoods as they were effectively 'people outside the plans' (Wall, 1996) (interview respondents, 2011).

The success of this awig-awig institution in the Gili islands more broadly, and its positive impact on coastal and coral reef management specifically, was the result of the "high level of local involvement in forming the rules" (Curran, 2011: 19), however and crucially, the success of this community-led marine management model was possible because there was consensus by national and regional government departments to protect the marine resources (Wever et al., 2012). This mutual 
understanding and shared action between the local community and authorities was strictly limited to governance of the sea. The protection of the mangroves and beach areas continue to be threatened by state policies and legislation that increasingly favors large-scale tourism development.

Subsequently, the impact of the recent and rapid tourism development is noticeably changing the island's marine resources: “. . . there is too much change. I snorkel so I see the change. The coral was much better. Now it's getting broken and it is getting less. The fish are fewer too. Diving and anchors are breaking the coral" (Respondent 10). The challenge for SATGAS, Gili Ecotrust and the Gili Dive Association remains how to manage a finite natural resource that they, and the island's community, rely on for their livelihood from dive tourism and from fishing.

c) Decentralization and Land Reform

The decentralization process began in Indonesia with the passing of the Autonomy Act in 2001 which gave greater financial, fiscal and administrative powers to the regional and local governments to set their own policies across a large range of areas including education, health care, economic development and environmental management. Within the first three to four years of the Autonomy Act thousands of new regulations were enacted by regional government across many sectors, but "more than 7000 [regulations]... [did] not comply with the higher authority laws and regulations" (Dirhamsyah, 2006:78). In addition, Butt (2010) argues that it has caused 'legal disorder' and has added unnecessary 'bulk and complexity' to the already sizeable and complicated Indonesian legal system. As noted by various authors (Fallon, 2001; Dirhamsyah, 2006; Aswicahyono, Bird and Hill, 2009; Tyson, 2010; Wever et al., 2012; Graci, 2012) Suharto's legacy of corruption, collusion and nepotism flourished during the period of instability (1998-2001) as the process of decentralization gave more power to regional elites and entrepreneurs to control the resources within their jurisdiction. Under decentralization, significant flows of funds of over US\$200,000 were dispersed from central government to the local level for tourism development on an annual basis (Furqan and Puad Mat Som, 2010). However, in the case of Gili Trawangan 'no financial assistance' has ever been offered by the Regency (Graci, 2012); despite tourism's significant contribution. An observation from a local tourism entrepreneur (Respondent 23) that “. . . huge amounts of money have changed hands with the head of the three islands to push these things [resorts] 
through" suggests that Suharto's legacy still strongly influences the rapid and unplanned tourism development on Gili Trawangan.

The 2011 Land Reform Act has to some degree clarified many issues related to land use rights and ownership, however this seems to have been selectively communicated so far. The preference for high-end tourism development appears to be the driver behind this, as observed by one local accommodation owner and resident of 18 years who found that "they keep it [development plans] quiet so no-one knows. Only the big players", and also by another government official who observed "we can see businessman on the beach here, but we can't control [it]. We have no say in these matters. We can't control." This view was also shared by established local and nonlocal actors - "When we talk about things on the island with people who have been here for a long time - the expats, the business owners, the investors - there is obviously a lot going on behind the scenes with the government that we have no idea about. Decisions are being made and policies are being implemented that we just don't know about" (Respondent 21).

The outside investors, on the other hand, and particularly those who do not reside permanently on the island or have recently invested in land, hold contrary views to the majority: "There are two rules, one for them and one for us. We pay the taxes and we do everything by the law and to the last letter and they just go around doing what they please. They are like the mafia. It's like a total mafia who can do what they want" (Respondent 13). This view clearly demonstrates the frustration of outside actors who, in spite of complying with recent national planning policy and legislation when setting up their business, feel powerless and perhaps threatened by the capacity of the community to resist change.

Aside from major development projects, the informal sector is also expanding rapidly with many workers commuting by small outrigger boat to Gili Trawangan from Lombok to sell everyday items such as cigarettes, sun cream and snacks to tourists on the beach, or to work in the restaurants, bars and hotels. There are growing concerns particularly from the local people over personal safety as the number of informal workers and informal businesses has increased considerably while the regulations governing this particular sector remain elusive.

Evidently the policy and planning process on Gili Trawangan is still in its infancy and this may explain why support from regional government to the local people and the island's natural integrity seems ad hoc, unclear and somewhat 
piecemeal. Three examples illustrate this. One example is that the pricing structures for public services (operated by government appointed companies) are very unclear and are not based on the size or profitability of the establishment, but rather on the type of relationship between public service operator and local government. A second example is that there has been little intervention in securing a clean, cost-effective and sustainable solution to the island's limited fresh water supplies. The wells in the most densely populated areas are saline and some have become contaminated with 'grey water' seeping into the water table (as observed during the 2011 fieldwork). The island's lack of potable water means that desalination has become an affordable investment for the larger establishments but an unaffordable luxury for many smallscale tourism entrepreneurs. The final example concerns sewage and its disposal. This is undoubtedly a worsening problem in the island and without proper intervention and policy, this will increase in line with the continuing growth in tourists and larger accommodation units (Hampton and Hampton, 2009). Respondents who are divers commented on observing algal blooms flourishing around areas of seepage and unpleasant odors often permeating the immediate tourist area which included beachfront restaurants and bars.

This section resonates with Satria et al.. (2006) observations of conflict between (a) the fishers and marine tourism (external-allocation conflict) and (b) the national and local government (management mechanism conflict) on Gili Trawangan in the early 2000s; however there are noticeable changes that seem to mirror the pace of tourism development on the island in the first and latter half of the 2000s. 'Management mechanism conflict' continues to exist on the island, however this has become more complex with the recently appointed regional government (North Lombok regency) in 2008, adding to the tensions between national and local government. 'External-allocation conflict' also continues however the emphasis is with land-based policy and use rights, and not the sea, subsequently the conflict now arises between established tourism businesses (including local people and long-term expats) and the external investors.

\section{SOCIAL RELATIONS AND POWER}

Tourism has been the key driver of socio-political change on Gili Trawangan in the last thirty of the island's forty years of human settlement. Unlike popular destinations in Lombok and Bali such as Senggigi and Nusa Dua, the development of the island's 
tourism economy was 'organic' and bottom-up without strategic direction, planning or support from national or regional governments. Without the challenges of modernization, tourism developed from the island's small, relatively homogenous community and its traditional laws (adat) of land ownership and usage, and was able to do so, although with increasing difficulty, until the beginning of the twenty-first century. The growing popularity of Gili Trawangan as a tourist destination since the early 2000s, and its role within regional economic development plans has led to a growing "heterogeneous, 'neo-traditional' population" (Wever et al., 2012: 66), adding new layers of power to the community structure and further challenging customary laws. In this process, the gradual erosion and marginalization of smallscale tourism entrepreneurs has undermined their legitimacy as local powerful actors and tourism stakeholders on their own island. This has appeared to divide local loyalties and create conflict between once broadly cooperative, relatively homogenous ethnic groups ${ }^{22}$.

In order to gain a more nuanced understanding of the changing forms of power through tourism development on the island parallel with the growth of national reform, economic development and decentralisation plans, Barnett and Duvall's (2005) taxonomy of power model is applied. As noted earlier, the traditional concept of power limits analysis of the case study to only understanding the kinds of social relations through which power is produced. The taxonomy of power framework extends beyond the traditional concept by analysing the specificity of social relations ("power over" and "power to - ") to understand how the effects of power are produced. This is a good fit with the complexities of tourism development in LDCs. In the context of Gili Trawangan, where its political economy has been shaped by international tourism directly (more recently) but also indirectly through national policy and governance reforms over a longer time, the taxonomy of power model can be adapted to simultaneously map the changes in power over three distinct periods (1970-1990; 1990-2000 and 2000-2011). Table 1 represents the specificity and types of social relations between key actors on Gili Trawangan against a timeline from 1970 to 2011 and is referred to in the discussion. 
Table 1. The Taxonomy of Power on Gili Trawangan from 1970s to 2011.

$\begin{array}{lllll}\text { TIME } & \text { COMPUlsory } & \text { Institutional } & \text { Structural } & \text { Productive } \\ \text { Period } & \text { Power } & \text { Power } & \text { Power } & \text { Power }\end{array}$

\begin{tabular}{|c|c|c|c|c|}
\hline $\begin{array}{l}\text { 1970s- } \\
1990 \mathrm{~s}\end{array}$ & $\begin{array}{l}\text { - Headman (land } \\
\& \text { marine) }\end{array}$ & $\begin{array}{l}\text { - Traditional } \\
\text { rules and } \\
\text { regulations. }\end{array}$ & $\begin{array}{l}\text { - Early outside } \\
\text { investors } \\
\text { - Preferential land } \\
\text { allocation }\end{array}$ & $\begin{array}{l}\text { - Backpacker } \\
\text { tourists \& } \\
\text { developer } \\
\text { tourists }\end{array}$ \\
\hline $\begin{array}{l}\text { 1990S- } \\
2000 \mathrm{~s}\end{array}$ & $\begin{array}{l}\text { - Headman } \\
\text { (land) } \\
\text { - Gili Task } \\
\text { Force (marine) }\end{array}$ & $\begin{array}{l}\text { - Reform of adat } \\
\text { by regency. } \\
\text { - Environment } \\
\text { Protection Act } \\
\text { under central } \\
\text { government. } \\
\text { - Autonomy Act }\end{array}$ & $\begin{array}{l}\text { - Army-led land } \\
\text { evictions } \\
\text { - Army base } \\
\text { established }\end{array}$ & $\begin{array}{l}\text { - Gili Ecotrust } \\
\text { - Dive tourists }\end{array}$ \\
\hline $\begin{array}{l}2000- \\
2011\end{array}$ & $\begin{array}{l}\text { - Regional } \\
\text { Government } \\
\text { (land) } \\
\text { - Outside } \\
\text { Investors (land) }\end{array}$ & $\begin{array}{l}\text { - Revitalise } \\
\text { awig-awig to } \\
\text { protect fisheries. } \\
\text { SATGAS } \\
\text { established. } \\
\text { - North Lombok } \\
\text { Regency } \\
\text { established. } \\
\text { - Land Reform } \\
\text { Bill passed } \\
\text { - Economic } \\
\text { Development } \\
\text { Master Plan } \\
\text { (2011-2015) } \\
\text { launched. }\end{array}$ & $\begin{array}{l}\text { - National interest } \\
\text { in tourism } \\
\text { opportunities } \\
\text { - Outside } \\
\text { investors and } \\
\text { migrant workers }\end{array}$ & $\begin{array}{l}\text { - Migrant } \\
\text { workers and } \\
\text { outside investors }\end{array}$ \\
\hline
\end{tabular}

Compulsory power is direct, intentional interaction between actors where goals are clearly articulated by a specific actor to another. During early tourism (and community) development the Bugis and Sasak groups were in a position to control the rate of tourism development and maintain power over the tourist developers with limited intervention from the state. The impact of 'socially distant' others, in this case the government, their ministries and the state was sporadic and temporary and although during the period of land invasions it could be argued that the army assumed compulsory power, this was short-lived. Thus during the first two decades of tourism development "the production and reproduction of internally related positions of super- 
and subordination, or domination that actors occupy" (Barnett and Duvall, 2005: 9) was minimal and the social discourse, knowledge and social norms of those living and working in Gili Trawangan remained unchanged. Competition for space along the coast and the coral reefs around Gili Trawangan between tourism entrepreneurs and fishers led to a conflict in marine resource use ${ }^{23}$. Through shared action and mutual understanding of local specific actors' (the headman and tourism entrepreneurs), control of the marine resource was given to the Gili Task Force while control of the land resource remained with the headman. There was a clear mutual understanding between the state and local actors in this case and even led to awig awig being reinforced to support local marine resource protection offered by SATGAS and later GET in the early 2000s.

Although the marine resource was granted some protection, the same could not be said for the land. The land reforms and recent decentralization and economic development plans have gradually limited the legitimacy of adat and awig awig to the point where they are no longer effective (Schellhorn, 2010: 131). It could be argued that the shift in the institutional power away from traditional towards modern rules and processes (Moore and Tjornbo, 2012) is just a product of global capitalism as opposed to tourism development per se. It could also be argued that tourism itself is just a product of advanced capitalism, and therefore the outcome for the local actors will inevitably be the same in the end, that is a loss of power and control over their fate. This somewhat simplistic conclusion is rather partial however, and does not explore or explain how social relations between actors are affected by power, nor how this changes the fate and goals of different individuals or communities.

Schellhorn's (2010: 132) observation that "the fact that tourism can alter relationships within the host society, including the power balance amongst different community subgroups, is often overlooked" lends support to Barnett and Duvall's criticism of the traditional concept of power and the inclusion of structural and productive power in the model. For small islands such as Gili Trawangan, this deeper analysis is perhaps more important as dependency on tourism is disproportionately greater than on larger islands ${ }^{24}$ in Indonesia and, in spite of national reforms and decentralization many local people have few opportunities for upward social mobility and many still live in poverty (Graci, 2012).

Rapid tourism development on the island seems to have become a 'divisive force' (Cole, 2008), and the mechanisms driving a wedge between specific actors are 
linked to recurring direct and indirect actions of the government(s) and the wider state. Over time the effect of institutional power has caused a "culturally alienating nature of chaotic land development" (Suartika, 2007: 174) and unclear guidance on individual and state land ownership and rights (Barron, Kaiser and Pradhan, 2009: 710). In doing this the structural positions, and thus power, of key local actors appears to have been undermined as outside investors and local tourism workers challenge their capacity to control community and tourism development and this has constrained and disadvantaged the local actors.

The effects of shifting power on the social relations between different actors resulted in 'weaker' actors accepting "their role in the existing order of things" (Barnet and Duvall, 2005: 53) without any resistance. This was particularly evident with developer tourists who appeared to have accepted their status as 'visitors' on the island from the start: “We are tourists on someone else's island no matter how long you have lived here or who you are married to." (Respondent 9) In other cases there was a resistance to change in the existing order - even when violence and intimidation was used : "The mentality of the local people at the moment is' build as much as you can on the land so they can't get us off'." (Respondent 21) This all suggests that a fourth taxonomy of power - productive power - is at work that is diffuse, intangible and more difficult to control.

Productive power is inherent in the short history of the island, its people and their ideology and this has been transferred to different actors through systems of knowledge and action over time. For example, the 'mentality' of the local people (as noted in the above quote) to resist change was established in the early 1990s and this was passed on to younger generations growing up on Gili Trawangan through learned actions, not knowledge: "In 1995 things started. The army came . . . and they cut the communications on the island. [They] had guns .Everyone came on the beach. [We] started to fight with the army. We went into the school and gave stones to the children so they could throw them at the army...All people were very angry. More angry than scared. It felt like a revolution." (Respondent 17 - Local Government).

Crucially this has produced social identities, social norms and meanings that "make possible, limit, and are drawn upon for action" (Barnet and Duvall, 2005: 56) at times when the local actors and their livelihoods have been threatened or intimidated. In fact, the local tourism entrepreneurs and local government who assumed compulsory power during the first two decades were able to do so because productive power was 
strongly linked to an ideology and identity that the majority of islanders shared ${ }^{25}$. It was not until the fourth decade of the island's history that a rapid rise in the number of outside investors, tourism workers and regional government officials present on Gili Trawangan seems to have finally and irreversibly tipped the balance of power away from local actors and in to the hands of 'socially distant others'. This has arguably been the main step change in community development on Gili Trawangan.

\section{CONCLUSIONS}

For many tropical LDCs, international tourism is economically significant in terms of income, employment generation and livelihoods and is often spatially concentrated at the coasts and islands. For the archipelago nation of Indonesia, its islands, especially Bali, have attracted significant international tourism since the 1970s as part of national development planning (Booth, 1990). Of the smaller Indonesian islands, the situation of Gili Trawangan in Lombok could appear to be just another tropical island destination facing rapid development. However this case study - that reports part of a longitudinal study since the late 1990s - examined the significant political and social implications.

Fieldwork revealed that the sense of identity that has evolved among longterm residents (20-30 years) of the island seems strongly linked to the environment. And this has, in part, contributed to some sense of island community. However with the rapid rise in tourism development and influx of economic migrants, investors and tourists, the social structure of the long-term resident community has fragmented further with new sub-groups driven by profit and growth, emerging and diluting the established social norms and structure of the island community. With a resident population of only around 1,900 people the consequences of this fragmentation appears to have created local conflict and social pressures which are exacerbating the underlying and serious problems associated with rapid unplanned, unregulated tourism development. The bottom-up (and unplanned) approach to tourism development before 2000 gave some broad structure to the ad hoc development and was successful because there was a loose, but effective dialogue and understanding among the community groups. This has all but ceased and subsequently the long-term residents continue to support and champion sustainable tourism and social development initiatives, but in isolation from one another. 
Land ownership has been a cause of conflict between central government and residents on Gili Trawangan since at least the mid 1990s. Overall, this issue has simmered in the background over this period but has flared up periodically. As tourism development has increased, so too has the demand for land and the corresponding bureaucratic procedures. As in many other LDCs, land has become a commodity that has no place for traditional sentimentalities of shared ownership; thus the role of the traditional kepala desa (village head) appears to be weakening as central and regional governments exert their power.

The influence of wealthy investors and land speculators within this process of power is clearly linked to their financial firepower, but perhaps less obvious is their influence in driving the bureaucratic process. The paper has argued that these groups have no reciprocal relations in Gili Trawangan, and appear to view the island merely as a business asset that is protected and managed within the legal framework of the country, which includes the title deeds or leasehold agreements for land occupied.

When considering the short history of this small island's development, the most notable change is the slow and dysfunctional transition of power from the community to regional and national government. This contrasts with the often studied processes of decentralization. Their interests are with tourism and the economic potential that further development will bring. The community is not necessarily part of the equation and subsequently appears isolated from decision-making (their only inclusion in this process is as victims of eviction or threats of eviction); the investors and speculators on the other hand are very much included in the process. Therefore the island community of Gili Trawangan - whilst in some senses demonstrating a level of resilience - in the final analysis very much remains the "people outside the plans ${ }^{26}$ (Wall, 1996).

Referring back to this paper's introduction and in the context of the case study, the evidence gathered suggests that the regional and national government have chosen tourism as a primary economic development tool for two main reasons. First, in comparison with the traditional economic activities such as fishing and agriculture, the tourism industry offers higher returns on investment in comparison and is not restricted by international legislation, market forces or dwindling stocks in the same way. This offers a route to rapid economic development and foreign exchange earnings for the region, and has been part of national development planning since 1969. The rise in tourists and growth in mass tourism and its associated infrastructure 
on the island throughout the 2000 s, is not a new plan but one that has gained credibility in view of this trend for upmarket tourism development and lucrative land lease agreements. Second, there is the central issue of land ownership and use rights that are connected with policy reform. On Gili Trawangan, it appears that outside investors are critical in developing the visitor economy with medium to large-scale resort developments, but they also appear to be important advocates for the government's land reform program and economic development plans.

Given the continuing significance of tourism for many LDCs with explicit and expected - economic impacts (employment, economic linkages, diversification, and contributions to GDP and revenue generation for governments), more work is still needed on political and social impacts on local host communities. In the academic sphere, as noted in the paper, there is a relatively small body of recent research on tourism for development in the mainstream international development literature. This present paper has contributed to the literature by focusing on the political economy of tourism in a small host community by using evidence from a longitudinal study. For planners concerned with small island tourism development in other LDCs, this Indonesian case study clearly illustrates the thorny issue of local, community control versus external control and questions what political levers may be available to allow the local community some measure of control over tourism development on 'their' island. The further discussion of power and ownership in tourism is timely, and has implications for a more nuanced understanding of this under-researched area. It also opens up the possibility of more effective tourism planning, and suggests the need for a growing awareness by policymakers of tourism's political and social impacts, and of how different types of power can shape host communities' development.

\section{ACKNOWLEDGEMENTS.}

The research on which this paper reports was partially funded by the British Academy (ASEASUK Research Committee), the Faculty of Social Sciences, University of Kent, and Kent Business School. The authors would also like to thank Bilge Daldeniz for her assistance with fieldwork and logistics, as well as the interview respondents who generously gave up their time. We also thank Perseverence Jeyacheya for his invaluable help turning sketch maps into figures. We are also grateful to Julian Clifton, Donna Lee and Stephen Royle for their helpful comments on an earlier version of the paper. The usual disclaimers apply. 


\section{REFERENCES}

Aswicahyono, H., Bird, K., and Hill, H. (2009). Economic Policy in Weak, Democratic, Post-crisis States: An Indonesian Case Study. World Development, 37 (2), 354-270.

Badan Pusat Statistik (Statistics Indonesia) (2014). 'Number of Foreign Visitors 1974 $-2013$

http://www.bps.go.id/eng/tab_sub/view.php?kat=2\&tabel=1\&daftar=1\&id_subyek=16\&notab=21

(Accessed 8 December 2014)

Baldacchino, G. (1993). Bursting the Bubble: The Pseudo-Development Strategies of Microstates. Development and Change, 24 (1), 29-51.

Baldacchino, G. (2010) Island Enclaves: Offshoring Strategies, Creative Governance and Sub-national island jurisdictions. Montreal, McGill-Queens University Press.

Barnett, M. and Duvall, R. (2005). Power in International Politics; International Organization, 59 (1), 39-75.

Barron, P., Kaiser, K. And Pradhan, M. (2009). Understanding Variations in Local Conflict: Evidence and Implications from Indonesia, World Development; 37 (3), 698 713.

Blackman, A., Naranjo, M., Robalino, J., Alpízar, F. and Rivera, J. (2014) Does

Tourism Eco-Certification Pay? Costa Rica’s Blue Flag Program. World

Development, 58 (1), 41-52.

Bertram, I. and Watters, R. (1985). The MIRAB economy in South Pacific Microstates. Pacific Viewpoint, 26 (3), 497-519.

Bianchi, R. (2002). Towards a New Political Economy of Global Tourism. In R. Sharpley and D. Telfer (Eds) Tourism and Development, Concepts and Issues. (pp. 265-299). Cleveden, Channel View.

Booth, A. (1990). The tourism boom in Indonesia. Bulletin of Indonesian Economic Studies, 26 (3), 45-73.

Bottema, M.J.M. and Bush, S. R. (2012). The durability of private sector-led marine conservation: A case study of two entrepreneurial marine s in Indonesia. Ocean and Coastal Management, 61, 38-48.

Bramwell, B. (2012). Governance, the state and sustainable tourism: a political economy approach. Journal of Sustainable Tourism, 19 (4-5), 459-477.

Brenner, L. and Fricke, J. (2007). The evolution of backpacker destinations: the case of Zipolite, Mexico. International Journal of Tourism Research, 9, 217-230. 
Briguglio, L. (1995). Small Island States and their Economic Vulnerabilities. World Development, 23, 1615-1632.

Britton, S. (1982). The Political Economy of Tourism in the Third World. Annals of Tourism Research, 9, 331-358.

Bunnell, T., Carl Grundy-Warr, C., Sidaway, J. and Sparke, M. (2012). Geographies of power in the Indonesia-Malaysia-Singapore Growth Triangle. In B. Derudder, M. Butler, R. (1980). The Concept of a Tourist Area Cycle of Evolution: Implications for Management of Resources. Canadian Geographer, 24, 5-12.

Butt, S. (2010) Regional Autonomy and Legal Disorder: The Proliferation of Local Laws in Indonesia. Sydney Law Review, 32, 177-191.

Chambers, R. (1983) Rural Development. Putting the Last First. Longman, London. Cole, S. (2004). Shared benefits: longitudinal research in eastern Indonesia. In J. Phillimore and L. Goodson (Eds) Qualitative Research in Tourism: Ontologies, Epistemologies and Methodologies. (pp. 292-310). New York, Routledge.

Cole, S. (2008). Tourism, Culture and Development: Hopes, Dreams and Realities in East Indonesia. Clevedon, Channel View.

Cole, S. (2012). A Political Ecology of Water Equity and Tourism: A Case Study from Bali. Annals of Tourism Research, 39 (2), 1221-1241.

Curran, E (2011) Underwater Coase: Can diving protect the coral reefs? Read at the European Association of Environmental and Resource Economists conference, 29 June - 2 July, Rome. Paper available at: http://www.webmeets.com/eaere/2011/prog/viewpaper.asp?pid=616 (Accessed 8 December 2014)

Cushnahan, G. (2004). Crisis Management in Small-scale Tourism. Journal of Travel and Tourism Marketing, 15 (4), 323-338.

Dahles, H. (2002). The Politics of Tour Guiding: Image Management in Indonesia. Annals of Tourism Research, 29 (3), 783-800.

de Kadt, E. (ed) (1979). Tourism - Passport to Development? Oxford, Oxford University Press.

Deutsch, A. (2011). Indonesia opens to infrastructure spending. The Financial Times, 16 December. Online at: http://www.ft.com/cms/s/0/d5ed922e-27cb-11e1-943300144feabdc0.html\#axzz2UCKTuy2z. (Accessed 24 May 2013).

Dickerson, H. (2008). Trouble in Paradise. Inside Indonesia, April-June edition. Dirhamsyah, D. (2006). Indonesian legislative framework for coastal resources 
management: a critical review and recommendation. Ocean and Coastal Management, 49 (1-2), 68-92.

Dodds, R., Graci, S. and Holmes, M. (2010). Does the tourist care? A comparison of tourists in Koh Phi Phi, Thailand and Gili Trawangan, Indonesia. Journal of Sustainable Tourism. 18 (2), 207-222.

The Economist (2011). Indonesia's Politics: Corruption Everywhere. Online. 2 September. http://www.economist.com/blogs/banyan/2011/09/indonesias-politics (Accessed 8 December 2014).

Fallon, F (2001). Conflict, Power and Tourism in Lombok. Current Issues in Tourism. $4(6), 481-502$.

Ferguson, L. (2010). Tourism development and the restructuring of social reproduction in Central America. Review of International Political Economy, 17(5), 860-888. Ferguson, L. (2011). Tourism, Consumption and Inequality in Central America. New Political Economy 16 (3), 347-371.

Furqan, A. and Puad Mat Som, A. (2010). Effects of Decentralization Policy on Island Destination in Indonesia. World Applied Sciences Journal 10 (Special Issue of Tourism and Hospitality), 63-70.

Gibbons, M.S. (2010) Islanders in Community: Identity negotiation through sites of conflict and transcripts of power. Island Studies Journal, 5 (2), 165-192.

Gili Eco Trust (2014). About G.E.T. Available from: http://giliecotrust.com/ (Accessed 8 December 2014).

Goreau, T., McClanahan, T., Hayes, R. and Strong, A., (2000). Conservation of Coral Reefs after the 1998 Global Bleaching Event. Issues in International Conservation, 14 (1), 5-15.

Gossling, S. (Ed) (2003). Tourism and development in tropical islands. London, Edward Elgar.

Goodwin, H. (2008). Pro-poor Tourism: a response. Third World Quarterly, 29 (5), 869-871.

Graci, S. (2010). Gili Trawangan, Indonesia: Collaborative Partnerships. In S. Graci and R. Dodds (Eds) Sustainable Tourism in Island Destinations. (pp. 121-132). London, Earthscan.

Graci, S. (2012). Collaboration and Partnership Development for Sustainable Tourism. Tourism Geographies. 15(1), 25-42. 
Guthunz, U. and Von Krosigk, E. (1996). Tourism development in small island states: from MIRAB to TOURAB. In L. Briguglio, B. Archer, J. Jafari and G. Wall (Eds) Sustainable tourism in islands and small states: issues and policies. (pp.18-35). London, Pinter.

Gurza Lavalle, A., Acharya, A, and Houtzager, P. (2005) Beyond Comparative Anecdotalism: Lessons on Civil Society and Participation from Sao Paulo, Brazil. World Development, 33(6), 951-964.

Hampton, M.P. (1998). Backpacker Tourism and Economic Development. Annals of Tourism Research, 25 (3), 639-660.

Hampton, M.P. (2010). Enclaves and ethnic ties: local impacts of Singaporean crossborder tourism in Malaysia and Indonesia. Singapore Journal of Tropical Geography, 31(2), 239-253.

Hampton, M.P. (2013). Backpacker Tourism and Economic Development: Perspectives from the Less Developed World. London, Routledge. Hampton, M. and Hampton, J. (2009). Is the Beach Party Over? Tourism and the Environment in Small Islands: a Case Study of Gili Trawangan, Lombok, Indonesia. In M. Hitchcock, V.T. King and M. Parnwell (Eds) Tourism in South East Asia: Challenges and New Directions. (pp.286-308). Copenhagen, NIAS Press.

Hampton, M.P. and Jeyacheya, J. (2013). Tourism and Inclusive Growth in Small Island Developing States. London, The Commonwealth Secretariat.

Hamzah, A. and Hampton, M.P. (2013). Resilience and Non-Linear Change in Island Tourism. Tourism Geographies, 15 (1), 43-67.

Harrison, D. (2008). Pro-poor Tourism: a critique. Third World Quarterly, 29 (5), 851-868.

Hein, P. (2004). Small island developing States: origin of the category and definition issues. In UNCTAD Is a special treatment of small island developing states possible? (pp. 1-22.) New York/Geneva: UN Conference on Trade And Development. Hitchcock, M. and Darma Putra, I. N. (2005). The Bali bombings: tourist crisis management and conflict avoidance. Current Issues in Tourism, 8(1), 62-76. Kamsma, T. and Bras, K. (2000). Gili Trawangan - from desert island to 'marginal' paradise. In G. Richards and D. Hall (Eds) Tourism and Sustainable Community Development. (pp. 170-84). London, Routledge. 
Khotari, U. and Wilkinson, R. (2013) Global Change, Small Island State Response: Restructuring and the Perpetuation of Uncertainty in Mauritius and Seychelles. Journal of International Development, 25(1), 92-107.

Lee, D., Hampton, M. and Jeyacheya, J. (2014) The political economy of precarious work in the tourist industry in Small Island Developing States. Review of International Political Economy. DOI: 10.1080/09692290.2014.887590

Marshall, J. (2001) Women and Strangers: issues of marginalization in seasonal tourism. Tourism Geographies, 3 (2), 165-186.

McCarthy, J. (1994). Are Sweet Dreams made of This? Tourism in Bali and Eastern Indonesia. Melbourne, IRIP.

McElroy, J.L. (2006). Small Island Tourist Economies across the Life Cycle. Asia Pacific Viewpoint, 47 (1), 61-77.

Mitchell, J. and Ashley, C. (2010). Tourism and Poverty Reduction. Pathways to Prosperity. London, Earthscan.

Ministry of Tourism and Creative Economy/ILO (2012) Strategic Plan for Sustainable Tourism and Green Jobs for Indonesia. Jakarta, International Labour Organization, Indonesia Office.

Moore, M-L., and Tjornbo. O. (2012) From coastal timber supply area to Great Bear Rainforest: exploring power in a social-ecological governance innovation. Ecology and Society 17 (4), 26-37.

Oberst, A., and McElroy, J. (2007). Contrasting Socio-Economic and Demographic Profiles of Two, Small Island, Economic Species: MIRAB versus PROFIT/SITE. Island Studies Journal, 2 (2), 163-176.

Organisation for Economic Cooperation and Development (OECD) (1967). Tourism Development and Economic Growth. Paris, OECD.

Picard, M., (1996). Cultural tourism and touristic culture. Singapore, Archipelago Press. (translated by D. Darling).

Royle, S.A. (2001). A geography of islands: small island insularity. London, Routledge.

Sasidharan, V, and Hall, M.E. (2012) Dominican resort tourism, sustainability, and Millennium Development Goals. Journal of Tourism Insights, 3 (1), Article 5.

Satria, A., Matsuda, Y. And Sano, M. (2006) Questioning Community Based Coral Reef Management Systems: Case Study of Awig-Awig in Gili Indah, Indonesia. Environment, Development and Sustainability. 8, 99-118. 
Schellhorn, M (2010). Development for whom? Social justice and the business of ecotourism. Journal of Sustainable Tourism, 18 (1), 115-135.

Scheyvens, R. (2002). Tourism for Development: Empowering Communities. London, Prentice Hall.

Scheyvens, R. (2011). Tourism and Poverty. London, Routledge.

Scheyvens, R., and Momsen, J. (2008). Tourism in Small Island States: From

Vulnerability to Strengths. Journal of Sustainable Tourism 16(5), 491-510.

Shareef, R. (2004). Country Risk Ratings of Small Island Tourist Economies,

Fondazione Eni Enrico Mattei, Note di Lavoro, Index No. 25.

http://www.feem.it/getpage.aspx?id=1211\&sez=Publications\&padre=73

(Accessed 8 December 2014).

Shaw B. and Shaw G. (1999). Sun, Sand and Sales: Enclave Tourism and Local

Entrepreneurship in Indonesia. Current Issues in Tourism 2 (1), 68- 81.

Silver, C. (2005). Do the donors have it right? Decentralization and changing local governance in Indonesia. In H. Richardson and C-H. Bae (Eds) Globalization and Urban Development. Advances in Spatial Science Series. (pp. 95-108). Heidelberg, Springer Berlin.

Stonich, S. (1998). The Political Ecology of Tourism. Annals of Tourism Research, 25(1), 25-54.

Suartika, G.A.M. (2007). Territoriality and the market system - Adat land vs. State regulations on land matters in Bali. Habitat International. 31, 167-176.

Theis, J. and Grady, H. (1991). Participatory Rapid Appraisal for Community Development. London, IIED.

Tyson, A.D. (2010). Decentralization and Adat Revivalism in Indonesia: The Politics of becoming Indigenous. Rethinking Southeast Asia Series. London, Routledge.

UNDP (2006). Maldives Diagnostic Trade Integration Study. UNDP, Geneva.

UNDP (2011). Tourism and Poverty Reduction Strategies in the Integrated

Framework for Least Developed Countries. UN Steering Committee on Tourism for Development. Geneva.

UNEP / UN WTO (2012). Tourism in the Green Economy Background Report. UN WTO, Madrid.

UN-OHRLLS (2013) List of small island developing states. New York, UN Office of the High Representative for the Least Developed Countries, Landlocked Developing Countries and Small Island Developing States. 
http://www.un.org/special-rep/ohrlls/sid/list.htm. (Accessed 16 July 2013).

UN WTO (2012a). Challenges and Opportunities for Tourism Development in Small Island Developing States. Madrid, UN World Tourism Organization.

UN WTO/ILO (2013) Economic Crisis, International Tourism Decline and its Impact on the Poor. Madrid, UN World Tourism Organization/International Labour Organization.

Vaisutis, J., Bedford, N., Elliot, M., Ray, N., Stewart, I., Ver Berkmoes, R., Williams, C., Witton, P. and Yanagihara, W. (2007). Indonesia. $8^{\text {th }}$ Edition. Melbourne, Victoria, Lonely Planet.

Wall, G. (1996). People outside the plans. In W. Nuryanti (Ed) Tourism and Culture.

Global Civilization in Change? Yogyakarta, Gadjah Mada University Press.

Weaver, D. (2012). Community-Based Tourism as a Strategic Dead-end. In T. Vir Singh (Ed) Critical Debates in Tourism. Clevedon, Channel View.

Wever, L., Glaser, M., Gorris, P. and Ferrol-Schulte, D., (2012). Decentralization and participation in integrated coastal management: Policy lessons from Brazil and Indonesia. Ocean and Coastal Management. 66, 63-72.

Winters, P. Corral. L. and Moreda Mora, A. (2013). Assessing the Role of Tourism in Poverty Alleviation: A Research Agenda. Development Policy Review, 31(2), 177202.

World Bank (2012a). Grenada: High-Level Forum Centers on Inclusive Growth, Job Creation. News Online. 11 December. http://www.worldbank.org/en/news/press-release/2012/12/11/grenada-high-levelforum-centers-on-inclusive-growth-job-creation

(Accessed 8 December 2014).

World Bank (2012b) Leveraging the Blue Economy for Inclusive and Sustainable Growth;.Small States Forum 2012 (SSF). 13 October. http://www.worldbank.org/content/dam/Worldbank/document/SSF-Seesion-1-BlueEconomy-Issues-Note.pdf (Accessed 18 October 2013).

World Bank (2014) World Development Indicators. http://data.worldbank.org/country/indonesia (Accessed 8 December 2014) Xiao, H. and Smith S.J. (2006) Case studies in tourism research: A state-of-the-art analysis. Tourism Management, 27, 738-749. 


\section{NOTES}

${ }^{1}$ According to the World Bank, a country is considered 'developing' if it has a GNI per capita of US\$11,905 or less. In 2013 Indonesia's GNI per capita was US\$3,580. (World Bank, 2014)

${ }^{2}$ Barnett and Duvall's (2005) taxonomy of power was based on global governance and is applied in the local context for this paper.

${ }^{3}$ Although there are official listings of SIDS consisting of $38 \mathrm{UN}$ member countries and 13 non-UN members (UN-OHRLLS, 2013) strangely there is a lack of an agreed international definition (Hein, 2004).

${ }^{4}$ For example in December 2012 the World Bank organized two different meetings in the Caribbean to discuss inclusive growth: an expert meeting on tourism, remittances and inclusive growth in Barbados; and a High Level Forum in Grenada, part of the Caribbean Growth Forum (World Bank, 2012a).

${ }^{5}$ Pro-poor tourism (PPT) is a development strategy that aims to maximize the benefits of tourism to the poorest communities in LDC destinations specifically. It is principally a poverty-reduction strategy aimed at improving the welfare and livelihoods of host communities.

${ }^{6}$ More recently there have been occasional papers published on tourism in World Development such as Blackman et al. (2014) on ecotourism certification but that topic lies outside this present paper's focus on tourism for development.

${ }^{7}$ The growing discussion around tourism and inclusive growth strategies, specifically by international development organizations, ties in with UNDP Diagnostic Trade Integration Studies (DTIS) of LDCs that took place during mid to late 2000s. In 2011, UNDP published a comprehensive paper that analyzed DTIS from 30 least developed nations where tourism is a primary economic policy objective. DTIS are comprehensive reports analyzing the macroeconomic and trade policies and performance of a LDC (see Maldives DTIS 2006 study for example). The UNDP working paper (2011) concluded that 'countries must do more to address pro-poor concerns, gender issues and sustainability considerations in tourism development' (p4). Half of the 30 DTIS had 'serious shortcomings' in their analysis by not considering inclusion and participation at the local level. Other concerns reported that partial information on appropriate tourism development, social and environmental 
sustainability and political stability and security did not address these critical issues adequately.

${ }^{8}$ The main short-haul markets were Singapore, Malaysia, Japan, Taiwan and Australia. These remain key markets nearly 20 years later but with growing interest from China. The principal long-haul visitors were from the UK and the Netherlands. ${ }^{9}$ There are exceptions, generally from anthropology with extended periods of fieldwork (see Picard, 1996 and Cole, 2008 for instance).

${ }^{10}$ The word 'Gili' in Sasak means 'island' and there are other Gilis around Lombok's coast, but Trawangan and its two sister islands (Gili Meno and Gili Air) have become the most well-known for international tourists.

${ }^{11}$ The immediate area includes the jurisdiction of the North Lombok Regency.

${ }^{12}$ Between 1996 and 2003 the estimated resident population grew from 400 people (Hampton, 1998) to 1089 (Satria, Matsuda and Sano, 2006).

${ }^{13}$ At the national level, strategic level planning is carried out by the Ministry of Tourism and Creative Economy, but, given the moves to decentralization and reforms since 1999 (Silver, 2005), lower levels of government such as the provincial governments also have some responsibility for tourism planning, in addition, some of the lowest level of government - regencies - within provinces also may have a tourism function. This structure of multiple levels of government involvement has been criticized for facilitating opportunities for rent-seeking, corruption and increasing inefficiencies as significant flows of funds are allocated to lower levels of government (The Economist, 2011).

${ }^{14}$ The fast speedboats taking a couple of hours replaced a slow, tedious route involving a ferry from Bali to southern Lombok, lengthy minibus rides across Lombok and a final crossing in a small traditional outrigger boat launched from the beach. Depending on the timing of Bali ferries, this sometimes necessitated an overnight stay on Lombok as the small boats to Gili Trawangan could not operate at night. This lengthy journey was suitable for backpackers on extended trips, but was less attractive or practical for other tourists such as families or those taking shorter trips.

${ }^{15}$ Backpackers had used the islands as a rest stop on their overland route eastwards to Komodo and Flores as a place for a 'holiday within a holiday' (Hampton and Hampton, 2009). 
${ }^{16}$ Access to Gili Trawangan is increasing with the new Lombok airport that opened in 2011. The new airlines operating between Lombok and short-haul markets such as Australia, include Jetstar which began operating a direct route between Perth and Lombok in 2013 and Air Asia with daily flights between Kuala Lumpur and Lombok. This is likely to increase the flow of tourism to Gili Trawangan.

${ }^{17}$ Indonesia's agrarian reforms in 1960 unified two systems (customary adat land tenure and the colonial, western land tenure) as part of the transition to a market-based economy. Land tenure and management practices were nationalized and private investment and development partnerships encouraged to exploit the land resources (Suartika, 2007). Thus, in 1970 when Bugis and Sasak groups were invited by the Suharto government to relocate to Gili Trawangan, this was under aegis of the agrarian reform. Land became nationally registered and all land use/ownership was legitimized by title deeds, therefore the 100 hectares of land offered to settlers in the north of the island was legally formalized. It is unlikely however that these communities were aware of the impact these changes to land rights would have as many of them had little formal education beyond primary school and many were illiterate.

${ }^{18}$ Much of the literature on small island development notes the strong sense of independence typically found in many islands around the world although this may not be associated with formal independence in terms of an island's status under international law (see for example Baldacchino, 2010 on sub-national island jurisdictions).

${ }^{19}$ Although there were inevitable minor conflicts between different parts of the island community, respondents talked about the different economic sectors (coconut plantations, small-scale fishing, seaweed cultivation and increasing small-scale tourism) as not being in fundamental conflict with each other.

${ }^{20}$ The land reform bill took ten years to formalize and implement.

${ }^{21}$ Biorock ${ }^{\mathrm{TM}}$ is a patented technology that is designed to create artificial coral reef systems among other coastal defense systems that use an electrodeposition process. Artificial coral reefs grow on caged structures that are anchored in place and attract sea water minerals through electrolysis.

${ }^{22}$ Interestingly, Gibbons (2010) study of Madeline Island in Wisconsin, USA showed similar trends, although in this case the principal tourists were domestic and a large 
proportion were second home owners who remained on the island for longer holidays than non-home owners. There, contestation and conflict occurs between the different islanders and the tourists and relates to access and ownership of the island's resources. ${ }^{23}$ The extractive and destructive fishing practices were threatening the non-extractive and less destructive practices of the dive tourists and dive operators.

${ }^{24}$ Graci (2012) reported an estimated $80 \%$ of the island's families are now employed in tourism.

${ }^{25}$ It could be argued that Suharto was also a strong influence through installing and enforcing the standardized desa/kecamatan/kabupaten system of local government. ${ }^{26}$ Although this paper concentrates on islands in LDCs, a study by Marshall (2001) of Grand Manan Island, New Brunswick, Canada raises the issue of marginalization of certain groups as tourism development increases. In this case study, women and people 'from away' were not invited to participate in future planning for the island's tourism industry. Subsequently, Marshall concludes that “...it is probable that future tourist developments on Grand Manan are in jeopardy of contributing to the problems of social cohesion.... [and] there may be lost opportunities for the community to have a creative voice in its future." (2001:183). 